\title{
What is the importance of executing rituals 'correctly' and why do people continue to engage in them?
}

\author{
Author: \\ Hennie Viviers ${ }^{1}$ \\ Affiliation: \\ ${ }^{1}$ Department of Religion \\ Studies, University of \\ Johannesburg, South Africa \\ Correspondence to: \\ Hennie Viviers \\ Email: \\ hviviers@uj.ac.za \\ Postal address: \\ PO Box 524, Auckland Park \\ 2006, South Africa \\ Dates: \\ Received: 05 Nov. 2010 \\ Accepted: 19 Apr. 2011 \\ Published: 25 Jan. 2012 \\ How to cite this article: \\ Viviers, H., 2012, 'What is \\ the importance of executing \\ rituals "correctly" and \\ why do people continue \\ to engage in them?', HTS \\ Teologiese Studies/Teologiese \\ Studies 68(1), Art. \#978, \\ 10 pages. http://dx.doi. \\ org/10.4102/hts.v68i1.978
}

C 2012. The Authors Licensee: AOSIS OpenJournals. This work is licensed under the Creative Commons Attribution License.
Rituals, borne out of our embodied practical reason, are deeds that are counterintuitive in terms of cause and effect. From a cognitive point of view, two kinds of religious rituals can be identified: special agent rituals, where superhuman agents act on human patients (onceoff, highly emotional; e.g. initiations, weddings) and special instrument and patient rituals, where human agents act on superhuman patients (repeated, less emotional; e.g. sacrifices, Holy Communion). The idea of 'correctness' applies more stringently to the first kind than the second, for instance: Jacob's blessing of Ephraim and Manasseh in Genesis 48. Rituals stabilise, reconstitute and replicate our 'cosmos' or imaginative worlds as they realign our intersubjective relations. They are tenacious and persistent, because they evoke, usually in an emotional and motivational way, our sense of urgency, our deeply felt need to maintain sound social relations and our intuitive ability to form notions of a counterintuitive world. The aim of this article was therefore to highlight and illustrate the role our evolved mental tools play when conducting rituals, especially when conducting some rituals 'correctly' and others less stringently so. Furthermore, the psychological appeal that rituals have on the human mind was also explained.

\section{Introduction}

The phenomenon of ritual behaviour is a fascinating one. People across the globe engage in these regulated, patterned behaviours where their actions do not seem to guarantee the logically expected results, as normal human action would. Sometimes the link between deed and consequence seems to be closer, for instance a baptism where the water resembles the washing away of sins, as claimed by the participants. But often there is no conspicuous link: the biting of a ram's tongue amongst the Kham Magar in Nepal, as part of the inauguration of a new shaman, remains strangely bizarre, because our day-to-day experience of cause and effect, or deed and consequence, is obviously not in operation here (Boyer 2001:230). Yet, this element crucially contributes to the inauguration and has to be done correctly or the inauguration becomes flawed and nullified. In some cases, deviation from the normal prescription is allowed, for instance the offering of a cucumber instead of a bull amongst the Nuer in South Sudan and western Ethiopia, but in others deviation is not allowed, for example, a layperson may not replace the officiating priest or minister during a wedding in church (McCauley \& Lawson 2002:32). Why does 'correctness' stringently apply to some rituals but less so to others? Furthermore, why do people continue engaging in these strange acts if these acts, at least on the surface to modern observers, seem rather meaningless? Those that prefer to get married in a church usually answer that God unites a couple in a 'mysterious way', but, frequently, secular people are attracted by the same kind of ceremony. They experience that something is lacking if they neglect these socially accepted behaviours, even though they are not convinced of the interventions of supernatural agents. Thus, the question remains: why do rituals persist amongst both the religious and the non-religious throughout the world?

The aim of this article is not to revisit all the different schools of thought, both past and present, which have conducted incisive research on ritual theory and behaviour. ${ }^{1}$ My aim is merely to ruminate on the twofold question of the formulated title: the 'getting it right' when conducting rituals (which is stringent for some and more lenient for others) and the fascinating 'hold' that rituals have over humans, so that they will not let go of them. To answer these two questions,

1.As with most studies on ritual, DeMaris (2008), in his 'Introduction', offers a brief discussion of the state of research on ritual theory showing particular appreciation for the work of ritual theorist, Ronald Grimes. The emphasis on social context, the (pre-conscious) embodied nature of rituals, the treatment of rituals in their own right as having a primary generating and creative function instead of a referential or symbolic function, to name but a few insights, have become consensual amongst leading scholars in this field. When it When it comes to the Bible, Denaris (200. Testament (research in the bring us closer to the life of the early church. Consequently, he discusses baptism (one of the core rituals of the New Testament), as a typical boundary-crossing rite ('entry rite') instead of simply a rite of passage. Baptism then becomes a way of crossing over into a new community, as if becoming part of a new family (2008:24). Baptism in (archeologically reconstructed) Romanised Corinth became a 'symbolic inversion', a subversion of the Roman hegemonic control of water (2008:50). DeMaris (2008:91-111) also aptly demonstrates the generating function of ritual: a 'curative exit rite' is foundational for the structure of the Gospel of Mark's passion narrative - Jesus undergoes utter humiliation and degradation (death through crucifixion) in order to vicariously 'save' his group, in a similar vein to the scapegoat of Leviticus 16 and Jonah. 
it seems appropriate to use the cognitive science of religion approach, ${ }^{2}$ which has produced fruitful research over the past two decades or so. Cognitive science lays bare the way the human mind operates in constituting or structuring our realities or 'worlds'. It focuses, inter alia, on the mental tools we have developed to adapt meaningfully to our surrounds, both the immediate ('seen') reality and the greater ('unseen') reality. Rituals - these seemingly strange actions - come to us intuitively, just as normal actions flow from the intricate planning and conducting functions of the mind, as will become clear later on in this article.

My contribution comprises three focal points. Firstly, I describe, from a cognitive point of view, what a ritual is and what kinds of rituals can be identified. Secondly, I refer to an illustrating example of a 'correct' ritual from the Hebrew Bible, namely Jacob's blessing of Ephraim and Manasseh (Gn 48). Lastly, I aim to explain why rituals are so attentiongrabbing and tenacious; why they persist amongst humans the world over.

\section{The definition and types of rituals that exist}

In spite of the reductionism of a single definition of ritual and the inadvisability of defining its 'fuzziness' (Crossley 2004:32), Barrett (2004:126) offers a working definition, at least as a starting point for further deliberation: '... an event during which an agent acts on someone or something to bring about a state of affairs that would not naturally flow from the action.' We therefore have here a deliberate act that accomplishes a transformation of affairs that would not normally be the intention of the act. To sacrifice an animal to the gods to reconstitute the cosmos is different from slaughtering it for mere human consumption. To mark the difference, Humphrey and Laidlaw $(1994: 71,73)$ speak of the ritualisation (or ritual commitment) of an ordinary act, where the intentionality of the agent becomes counterintuitive.

Rituals are not empty-minded habits, although they are often repeated in stereotypical fashion. They are conducted deliberately at appropriate times, usually during crises, seasonal changes, or when societal changes occur (e.g. inaugurations, rites de passage) and so forth, and societies or the ritual practitioners intuitively sense or 'feel' that they should be conducted (Crossley 2004:41). Although not empty-minded, their meanings are not always transparent, neither to outsiders nor even to the insiders themselves. The meanings that the Shvetambar Jains in western India give to the flowers in the pushpa [flower] Puja [ritual of worship], ${ }^{3}$ where flowers are placed on a consecrated statue, are diverse, despite the fact that the same action is conducted on each occasion (Humphrey \& Laidlaw 1994:1, 34, 35). Humphrey and Laidlaw (1994:74) are adamant that rituals do not have

2.See, for instance, the Cognitive science of religion series, edited by Harvey Whitehouse and Luther H. Martin and published by Altamira Press.

3.'The daily Jain Puja or ritual of worship consists of bathing, anointing, and decorating a consecrated idol, a murti, and then making a short series of "offerings" to the ido Notionally there are eight of these operations, so the rite is often referred to as the "eightfold" (or ashta prakari) puja' (Humphrey \& Laidlaw 1994:1). intrinsic meanings, ${ }^{4}$ but that meanings are allocated to rituals by their respective communities; the rituals invite (propositional) meanings so to speak, in a similar manner to how a word begets a meaning through its usage. Although they do not have intrinsic propositional meanings, rituals are experienced as very meaningful, and this also explains why they persist both in the religious and secular sphere. Crossley (2004:31) refers to our pre-reflexive, embodied knowledge of which rituals are a part in that they '... are a form of embodied practical reason' upholding our constituted realities as they are performed as (bodily) acts. Following theorists such as Marcel Mauss, Maurice Merleau-Ponty and Pierre Bourdieu, Crossley (2004:35) refers to rituals as resembling the 'habitus', the incorporated 'facts' and 'truths,' 'common sense,' 'acquired ability' or 'faculty' that a society holds dear and that everyone ought to live. Even though the 'habitus' is a cultural construct, the fact that it has become sedimented throughout history gives it the status of the 'natural' (godgiven) and therefore it is non-negotiable. Crossley (2004:37) uses the example of swimming to illustrate this. Once one has mastered the knack of swimming, one does it without being able to put the practical understanding of water, motility and buoyancy of the body into rational discourse. ${ }^{5}$ In the light of rituals being embodied practical reason, it makes sense that they are treated as 'objects', something given to be enacted: 'we learn and remember ritual actions; we enact them as ourselves, and in that sense they are in us too' (Humphrey \& Laidlaw 1994:267).

What, then, is the purpose of rituals? They are indeed acts that are deliberately conducted to bring about a transformation of a state of affairs. They not only create, maintain and preserve the cosmos but also sustain and preserve it in general (Gruenwald 2003:75). ${ }^{6}$ Rituals are about the order and maintenance of the social stability of a society but also about the reproduction of that society (Crossley 2004:32-38), although not in an instrumental way, as one would impact on the natural world. Modéus (2005:42) expresses the latter succinctly: 'Ritual does not change the world, but it changes our experience of the world or enforces our present understanding of it' (see also Boyer 2001:255; Crossley 2004:38). Arguing in the same vein, Crossley (2004:46) emphasises that rituals change our subjectivity and our intersubjectivity, our individual psychological and social states. This happens in two ways, namely through the utilisation of emotion and imagination. To alleviate tension, or our intuitive sense of urgency (Boyer 2001:236-241) borne out of negative emotions such as fear or anxiety, rituals usually play an important role. For instance, to ease the fear brought about by some natural disaster in a pre-industrial

4.When we chant a mantra, which is often reduced to a single sound, or when a modern Roman Catholic congregation receives a benediction in Latin, which they do not understand, it becomes clear that the 'meaning' of these rites lie on anothe level than propositional meaning (Humphrey \& Laidlaw 1994:74). In regard to the wrongly assumed intrinsic meanings of rituals, DeMaris (2008:8) follows Ronald Grimes's argument here and agrees - one should avoid '.. interpretive frameworks that assume the referential or symbolic nature of rites'.

5. Humphrey and Laidlaw (1994:138) confirm this prior, pre-reflexive 'knowing' by discussing how 'a child knows what a house is before knowing the word "house"'.

6.A sacrifice in which the animal is cut into parts represents a rather crude mimetic act of the destruction of the cosmos; the eating of these animal parts by the participants simultaneously becomes life-enhancing, restoring 'life' in the cosmos. 
society, a sacrifice becomes the appropriate tool to appease the gods or ancestors who are assumed to be the responsible agents. Positive emotions can also be harboured by a shared ritual such as a bar mitzvah, where the shared joy of being Jewish is celebrated and signalled socially to all involved. Imagination implies the constitution of alternative realities, new 'worlds' accommodating the creative discovery of new subjectivities and possibilities of life-fulfilment. For example, whenever the philosopher Maurice Merleau-Ponty could not fall asleep, he would bodily imitate the posture and breathing of a sleeping person, emptying his mind and call upon sleep as Dionysian followers call upon their god by miming scenes from his life. Through this imaginative intending the world of sleep comes (as a god) and befalls him (Crossley 2004:42, 46). When the same physical world is viewed and experienced through new eyes, Crossley (2004:45) aptly speaks of '... a social form of "magic"'. ? Rituals do not only accomplish this 'mysterious' change in mainstream societal practices but also in counter-hegemonic lifestyles. In protest rituals, protesters transfer themselves imaginatively into an alternative 'world' through song and dance and usually the destroying of the symbols of their enemy. The symbol or effigy (e.g. a building) becomes a target through the magic of make-believe, bonding 'us' triumphantly over 'them' (Crossley 2004:47-49). McWhorter (2004) confirms the 'magic' referred to as she and her life-partner conducted a same-sex commitment à la the pattern of the ritual of marriage, ${ }^{8}$ but emptying it of its institutionalised 'normalising' contents. They wrote and designed their own ceremony, a 'queer rite of passage/ ing', with the latter implying the discovering of new selves and new others as they passed and proceeded into this new creative space of an alternative 'reality'. Their relationship transformed and richly deepened, as did their relationship with their immediate community. Their experience was one of '... askesis, an ethical practice of freedom' (McWhorter 2004:91), which also addressed humans' intuitive sense of maintaining sound intersubjective or social relations (Boyer 2001:241-255).

After these few cursory remarks on the nature of rituals, I will now highlight the kinds of rituals that can be found in human practice. Here the focus falls on religious rituals, where counterintuitive agents are involved. McCauley and Lawson (2002; see also McCauley 2004), on whom my contribution predominantly relies, offer their views decidedly from a cognitive scientific point of view, tapping especially into Cognitive Psychology and Anthropology. 'Cognitive' implies '... a research program concerned how human minds work, how they produce the kinds of cultural artifacts that they do, how they transmit (or ignore) these artifacts ...' (Martin 2006:393). McCauley and Lawson's

7.Boyer (2001:250-253) confirms 'the magic of society', where a current state of affairs, for instance, intuitively trusting your clan members more than outsiders, is ascribed to some hidden forces and processes which cannot be fully explained by our 'naïve sociology'. Boyer (2001:253), following anthropologist Maurice Bloch, explains this 'magic' as transcending people's naive sociology, built on the notion of a shared biology that a group of people 'share the same bones' or 'the essence of the clan is inside us'.

8.McWhorter $(2004: 82$, 84) follows Michel Foucault, who sees ritual as a '... technology of power, a highly versatile tool for imposing hierarchy and order, for managing populations, and for producing docile and useful types of human selves'. managing populations, and for producing docile and useful types of human selves'.
However, because it is such a transformative tool, it can and should be utilised However, because it is such a transformative tool, it can and should be utilised
precisely for the opposite goal, a means of practicing (non-normalising) freedom.
(2002) views on religious rituals are described by their theory of action representation, embedded broadly in competence theories. With the latter they simply mean that humans have the same intuitive disposition for ritual as they have for the learning of language. Nobody needs to be a trained linguist to 'hear' when sentences are formed incorrectly in speech and one similarly 'knows' when a ritual is conducted wrongly. This also confirms Crossley's (2004) view of rituals as embodied knowledge (practical reason) operating on a pre-reflexive level (McCauley \& Lawson 2002:36).

McCauley and Lawson's (2002:8) theory of religious ritual competence has two commitments. Firstly, '.. the cognitive apparatus for the representation of religious ritual form is the same system deployed for the representation of action in general.' In other words, we do not have a special mental capacity to conceptualise religious ritual. The structure of the rituals on which they are focusing is independent of the attributed meanings by participants. Secondly, the role of culturally postulated superhuman agents (CPS-agents or gods) is pivotal in the structuring of religious ritual. CPSagents also determine the difference between ordinary and religious rituals.

The action representation system, the core of McCauley and Lawson's (2002:14) theory, states that religious action is also just action. It acknowledges the insights of Cognitive Psychology that humans possess a mental system or tool to detect agency (agents acting in a deliberate way) known as the hyperactive agency detection device (HADD; see Barrett 2004:31-44, 107-118). This mental device or 'antenna' overdetects and often mistakes illusions of agency for the real thing. The ability to detect agency is remarkably present even in babies. Along with this tool, humans also have a theory of mind (ToM; see Barrett 2004:31-44, 107-118) to make sense of what is detected. A ToM is a kind of a 'mindreader' which determines the desires, wishes and beliefs of the agent in question. The action representation system builds on these insights to present rituals consisting of an agent, acting (through an instrument) on a patient (the 'receiver' of the action) to reach some kind of goal. Along with these tools we also have social facilitators that regulate our social interactions, establish and maintain morality and confirm our group ties (Barrett 2004:3-6, 45-60). These same social competencies are also utilised for interaction and transactions with CPS-agents (McCauley 2004:167-168). Not all actions that form part of rituals can qualify as rituals in the technical sense of the word. Kneeling during prayer is only an action, whilst the prayer itself constitutes the ritual, where a certain transformation of events is the desired goal (McCauley \& Lawson 2004:14-15). Furthermore, an outsider can act (e.g. pray along with others), but only an insider can take part in the actual ritual (e.g. Holy Communion). A ritual is always embedded within a chain of previous rituals, whilst a mere act need not be (McCauley \& Lawson 2004:15-16). The enabling rituals preceding a specific ritual, and ensuring its effectiveness, are aptly summarised by McCauley and Lawson (2002) in the following example: 
The efficacy of the ordination of a monk in Theravada Buddhism, for example, will have derived from the officiating monk's legitimacy, the appropriate ritual history of the water used in the ritual bath, and the eligibility of the patient. The bathing itself and the previous act of consecrating the water are qualified by the fact that the officiating monks are eligible to carry out such ritual acts. If they are imposters, ritual failure looms. Minimally, it contravenes basic assumptions about the relations between various ritual actions and about those rituals' connections with CPS-agents. (p.17)

The role that CPS-agents play in these enabling actions is determinative for their efficacy. It is also important to note that the buck stops with the involvement of CPS-agents in the different enabling rituals (McCauley \& Lawson 2004:20). Once a child has been baptised, even by the priestly representative of a god, the ritual need not be repeated. What then makes these CPS-agents so special? For one, they are believed to have 'strategic information' (Barrett 2004:46, 51, 90; Boyer 2001), a god's eye view on all earthly affairs which gives them power to act decisively. Humans also tend to over-ascribe responsibility to agents, both human and superhuman, and therefore the gods come in very handy to explain the causality of otherwise unknown or mysterious happenings (McCauley \& Lawson 2002:21). For instance, it is easier to make a 'person' responsible than to look for deep scientific reasons as to why lightning struck a specific person at a specific spot in a dwelling. Once the god has acted in a ritual, no further questions need to be asked, their supernatural (counterintuitive) capabilities legitimise what they have assumedly done. Although these gods are often treated as 'humans', they exceed humanness through their supernatural powers. ${ }^{9}$

Building on the above, McCauley and Lawson (2002:26-29) profile three distinct rituals, namely, special ${ }^{10}$ agent rituals (e.g. circumcisions, weddings, funerals), special instrument rituals (e.g. divination) and special patient rituals (e.g. sacrifices, rituals of penance, Holy Communion). Here, the principle of superhuman agency (PSA) and the principle of superhuman immediacy (PSI) work together to categorise the structures of these ritual profiles. The PSA is concerned with how the CPS-agents are involved (their roles in a ritual as actors or acted upon) and the PSI concerns their immediacy in a ritual through enabling rituals (i.e. 'depth') (McCauley \& Lawson 2002:28). These two principles let the first ritual stand alone (god or representative is the agent) and group the remaining two together (god is the patient). An imposter instead of a god or representative in a special agent ritual disqualifies it as well-formed and, although the conduct of the other two rituals require some punctuality towards the god as patient, its effectiveness cannot be guaranteed (e.g. a sacrifice can be rejected). The PSA determines that special agent rituals are not repeatable (the buck stops with the gods), whilst the other two are (they effect only temporary grace). Indeed, because of their effects of temporary grace, the latter two types of ritual do not need to be reversed, whilst the consequences of a special agent ritual can be

9.DeMaris (2008:28) accepts the once-off performance of baptism, but does not offer specific reasons for this non-repeatable action.

10."Special" as Lawson and McCauley put it - that is connected to supernatura agents' (Boyer 2001:259) (e.g. the defrocking of a priest). In addition, substitution can happen in special instrument and patient rituals (e.g. a Muslim can use sand for cleansing instead of water and 'among the Nuer it is auspicious to sacrifice a bull, but since bulls are particularly valuable, a cucumber will do just fine most of the time' [McCauley \& Lawson 2002:32]), but a priest cannot be substituted by a lay person in a special agent ritual. The PSI determines a ritual's centrality: the 'closer' a CPSagent is in a particular ritual through enabling actions, the more central it is and vice versa.

In their study McCauley and Lawson (2002:89ff.) decidedly interact with the ritual frequency hypothesis of Harvey Whitehouse ${ }^{11}$, who has identified two modes of religiosity, namely the deeply emotional imagistic (high sensory pageantry) mode, where the recall of events that are not performed frequently appears as 'flashbulb' (crisp and clear) memory. The second is the doctrinal mode (low sensory appeal), where the frequently repeated meditation and reflection on a religion's dogma lead to internalisation and its storage in the semantic memory, ${ }^{12}$ but also the possibility of 'tediousness'. These two modes coincide with the special agent rituals which stand out for their sensory pageantry and need to be conducted only once (e.g. circumcision), as well as with the oft-repeated special instrument and patient rituals (e.g. offerings), which are more often low key in emotionality and can become rather boring. The way that these two kinds of rituals become 'ingrained' in the mind, especially through the two kinds of memory mentioned, is as follows in regards to the highly emotional special agent rituals:

Our cognitive alarm hypothesis, then, holds that when current circumstances are the cause of emotional arousal, we will increase the attention and cognitive resources we devote to them, which in turn, will increase the probability of their subsequent recollection. But that sort of memory consolidation may only arise if that initial, heightened alertness receives ongoing vindication in subsequent experience concerning our sense of the event's significance. (We not only have no flashbulb memories for the false positives, we usually have no recollection of them at all). (McCauley \& Lawson 2002:78) ${ }^{13}$

11.Although McCauley and Lawson (2002:112-113, 147-149) generally agree with Whitehouse, they argue a strong case that form is the crucial variable in regard to the emotionality of rituals, rather than frequency. Their form hypothesis not only provides deeper theoretical depth, but is also able to predict two exceptions to the two major kinds of rituals. The latter, where they are in agreement with Whitehouse, describes oft-performed (low emotionality) special instrument and patient rituals and infrequently performed (high emotionality) special agent rituals. The exceptions, which Whitehouse's frequency hypothesis wrongly rituals. The exceptions, which Whitehouse's frequency hypothesis wrongly predicts, are, for instance, the Muslim hajj, which is a special patient ritual (but infrequently performed [high emotionality]) and the ring ceremony of the splinter group of the Dadul-Maranagi area of the Kivung people of Papua New Guinea (where Whitehouse conducted his fieldwork), which is a special agent ritual (but
oft-performed [high emotionality]) (2002:150, 155-178).

12.Following the argument of Endel Tulving, McCauley and Lawson (2002:77) explain the difference between these two types of memory as follows: 'Flashbulb memories are a special sort of episodic memory, typically characterized by elevated levels of vividness, confidence, and, as we have seen, sometimes even accuracy. Episodic memories concern recollections of specific events in a person's life. Memories for such specific episodes constitute the core of a person's sense of his or her unique life history. Semantic memory, by contrast, is the general knowledge of the world that people may have.'

13. Here, McCauley and Lawson (2002:78) follow Antonio Damasio, who describes and locates the neural base of the cognitive alarm system in the subcortical any amygdala (underneath the brain). The amygdala plays an important role in coordinating cognitive and bodily states (including the bio-chemical patterns underying emotions) and communicating these to the rest of the nervous system, determining our immediate behaviour. Damage to the amygdala implies that people can comprehend danger, for instance, but lack the appreciation to act appropriately. 
The two less emotional rituals become ingrained in the memory of their proceedings through repetition. By repeating them, the ritual practitioners develop an implicit script, of which the ritual is a prototype: 'A script is a cognitive representation for a "predetermined, stereotyped sequence of actions that defines a well-known sequence of actions"' (McCauley \& Lawson 2002:49, citing Roger Schank \& Robert Abelson; see also Humphrey \& Laidlaw 1994:112, 128).

To summarise, even though rituals as bodily acts of a special kind that do not abide by the normal law of cause and effect (non-intentional), seem to be empty-minded, repetitive habits, they are not. They are deliberate acts that effect real ('mysterious') changes, even though these changes are only operative on the subjective and intersubjective level. We have an intuitive (pre-reflexive) sense for conducting rituals correctly at the appropriate times, and immediately sense if they are faulty, just as we 'hear' during speech when language is constructed awkwardly. A cognitive view on religious rituals relies on our overwhelming natural sense of agency (as well as assumed superhuman agency) and the mental tools to shape our reality. Cognitive insights lay bare rituals of two kinds, namely those where things are done to the gods or ancestors (special instrument and special patient rituals) and those where these counterintuitive agents do certain things to their patients (special agent rituals). Rituals persist and are attention-grabbing because they appeal to our intuitive sense of agency, our emotions and motivations and our lively imaginations.

\section{Getting it right! The case of Jacob's blessing of Ephraim and Manasseh (Gn 48)}

In what follows, the theoretical insights of ritual, and especially those of McCauley and Lawson (2004), will be put to the test with an example from the Hebrew Bible. Even though only a cursory, illustrative explication of Jacob's conduct of his 'deathbed-testament' or will (Mitchell 1987:81) will be presented, ${ }^{14}$ it will suffice to show how this specific ritual neatly fits its general profile, as presented earlier. The blessing of Jacob of the House of Joseph (or Rachel tribes) through his two Egyptian born sons, Ephraim and Manasseh, is presented in Genesis 48, even though the last wishes of the elderly and dying Jacob commences in Genesis 47:28 and proceeds through Genesis 49. Although the latter chapter creates the impression of a continuance of the blessing ritual, it is more of an optative prophecy (Mitchell 1987:86) than a proper ritual. The blessing, or to phrase it better, the legitimisation of Ephraim and Manasseh as Israelite tribal heads, fits the profile of a special agent ritual. A special agent ritual is a once-off (non-repeatable) ritual where a superhuman agent, such as a god (or ancestor) acts decisively, usually by a legitimate representative, through a specific action (e.g. ordination, initiation) on a patient. This kind of ritual is usually accompanied by sensory pageantry that evokes strong emotions and, consequently, a clear and exegesis, but is simply an exercise in 'reading the text ritually'. crisp ('flashbulb') recall. What makes the blessing of Jacob interesting is the demand by Joseph that the 'script' of blessing the firstborn with the right hand should be adhered to. A 'script' or prototype of action, to, inter alia, aid (semantic) memory, usually fits the other two kinds of rituals, namely the special instrument and special patient rituals, that are often repeated. But even in the case of a once-off ritual, such as the one we have here, the ritual practitioner does repeat the ritual, ${ }^{15}$ but with different patients who receive its benefits only once. Joseph's demand therefore 'to get it right' makes good sense. However, before paying attention to the blessing ritual itself, a few remarks are needed on the text.

The Joseph novelette (Gn 37, 39-50) placed towards the end of Genesis provides the Israelites with a catching story of how they got into Egypt and how they returned from there to the so-called Promised Land of Canaan. Even though comfortably settled in Egypt and on friendly terms with the Pharaoh, thanks to the good work of his Israelite vizier Joseph, Egypt is not their home. Their future lies in Canaan (Westermann 1982:205). The last death-bed wishes and actions of Jacob towards the end of the Joseph story also serve important etiological functions, that is, they explain why things are as they are: how it came about that Ephraim and Manasseh were elevated to the position of Israelite tribal heads, even though they were born to Joseph through his Egyptian wife Asenath, how they landed up in the Samarian ${ }^{16}$ highlands to occupy this specific area of Canaan, how Ephraim, who was not the firstborn, surpassed his firstborn brother, Manasseh, in status and importance in Israelite history, how the House of Joseph (later the Northern Kingdom) received the same status as Judah (later the Southern Kingdom), and so on. Ritually speaking, Jacob's last days became a time of transition, when people intuitively sense that it is time for a ritual to ensure the orderly continuity or replication of the specific culture or community. The time of transition in need of ritual, in this case, is eloquently verbalised by Westermann (1982):

Der Segen des Vaters reicht von einer Generation zur nächsten hinüber und schafft eine Kontinuität zwischen ihnen. Er erhält eine höhe Bedeutung beim Übergang von einer Epoche zur anderen. Mit dem Tod Jakobs geht die Väterzeit zu Ende, der Aufenthalt in Ägypten leitet die Zeit des Aufzugs und dann des Ansiedelns in Kanaan ein. ${ }^{17}$ (p. 218)

Source critics have pointed out the 'unevenness' of the text of Genesis 48 (Von Rad 1972:412), with the so-called Yahwist (10th century BCE), Elohist (9-8th century BCE) and Priestly (post-exilic) sources identifiable as follows: Genesis 48:1-2 is Elohistic (see e.g. the name Jacob; Speiser

15.We find a similar example in the act of marriage, where a priest or marriage officer will often repeat the same rite, but not with the same two recipients.

16.The source of the acquiring of Samaria through the sword and bow of Jacob in Genesis 48:22 remains somewhat of an enigma. It is not known whether Jacob ever acquired this 'shoulder' (שכ his sons Simeon and Levi for committing such violence (Gn 34, 49:5-7) (Von Rad 1972:419).

17.The Exodus became Israel's dominant myth in their history, which is questioned by historical and sociological research pointing rather to a revolutionary upsurge by histy Israelite clans present in Palestine (ing rather to a revolutiona upsurge by early Israelite clans present in Palestine (e.g. Gottwald 1979, 1985). Even so, myth gives birth to ritual and rituals uphold their myths: '... myth generates ritual ... it begins as a statement of an imaged reality and moves on to become a behavioura argument ... ritual is a behavioural stance that creates transformative events, ofte in relation to that myth' (Gruenwald 2003:99, 113). People 'live in' and 'live out' their myths (discourses) whether they are true or not. Gruenwald (2003:101) interestingly notes that although animals have rituals as well, they have no myths. 
1964:359), which repeats the Yahwist's version of Jacob nearing death in chapter 47:29-31 (see e.g. the name Israel and 'hand under the thigh' form of oath; Speiser 1972:359). The Priestly narrator's hand can be detected in chapters 47:28 and 48:3-6 (see e.g. references to fertility [Gn 47:28; Gn 48:4], El Shaddai [Gn 48:3], the 'assembly of tribes' [Gn 48:4] and Paddan [Gn 48; 7, which is perhaps an addition to vv. 3-6]; Speiser 1972:359). Then, chapter 48:8ff. seems to be a fusion of the Yahwist and Elohist sources, with the poetic insertion of verses 15-16, which clearly interrupts the flow between verses 13-14 to 17-19 and the final repetition of the blessing in verses 20 (Speiser 1972:359; Von Rad 1972:413).

An 'even' reading of chapter 48 would suggest the following sequence: verses 1-2 (Joseph and his two sons visiting the dying Jacob), verses 8-14 (build up to the blessing proper by kissing and embracing the two sons and Joseph positioning them correctly to receive Jacob's blessing), verses 17-19 (Joseph's attempt to correct Jacob's hands to 'get the ritual right' and his 'wise' refusal), verse 20 (the blessing proper). However, insertions in the text, from later sources (Priestly) or other redactional activity (probably vv. 15-16), are intended for good reasons and contribute further meanings. Verses 3-6 and verse 7 emphasise that not Egypt but Canaan is the Israelites' true home (Hamilton 1995:629) and verses 15-16 are presented as part of, or a build up to, the actual benediction in verse 20 (Jacob speaks in the third person about them in vv. 15-16, but addresses them directly in the second person in v. 20). Apart from literary and other reasons for these additions, they also fulfil interesting ritual functions, as will be shown shortly.

Special agent rituals are characterised normally by a rich sensory pageantry accompanied by a conspicuous emotionality. What we have in Genesis 48 is obviously only a 'world of words' (also the added words) and not a live performance. We can only infer from the text what the narrator(s) provide us and fill in gaps here and there in an informed way. We are not provided with explicit references to attention-grabbing accoutrements in the form of clothing, setting, et cetera. We do, however, have some hints of strongly felt emotions. Genesis 48 begins in a solemn way, as we are informed of the aged Jacob's illness and his reaction when receiving his son and grandsons. $\mathrm{He}^{\prime}$ '... rallied his strength and sat up on the bed' (v. 2). This could be a sign of deference to Joseph who was, after all, second-in-command after the Pharaoh, but was very likely an attempt to position himself properly to conduct the blessing ritual to follow. Sitting up on his bed distinguishes him as an ordained leader on his throne ('troonzetel'; Van Selms 1973:266). The Priestly source (vv. 5-6 and v. 7) adds a moving moment, as Jacob 'adopts'18 Joseph's two sons as his own, ${ }^{19}$ putting them on par with his own two firstborns, Rueben and Simeon. As such, they are integrated fully into the House of Jacob, making them part of the Israelite ancestor lineage that started with Abraham and

18.'Adoption' of the two sons here should rather be understood as 'legitimise' as fully Israelite, as Joseph still remains the true father of the sons (Westermann 1982:208; see also Hamilton 1995:629).

19.The final compilers have created a catching subtlety. In Genesis 48:1, the two sons are identified according to primogeniture, that is, first Manasseh and then Ephraim; yet, in Genesis 48:5, Jacob changes this as he speaks of Ephraim first and then Manasseh, offering a prelude of what is to happen later on (Van Selms 1973:271)
Isaac. Joseph's association with Jacob's beloved, Rachel, as her 'firstborn', meant that his offspring probably triggers Jacob's memory of her. The offspring that was denied her through an early death can therefore continue through Ephraim and Manasseh (Hamilton 1995:630). Jacob's expression of his fondness for these two sons continues in verse 10 and verse 11 , as he kisses and embraces them and expresses his utter satisfaction of being able to also see his grandsons and not only his loved firstborn from Rachel, Joseph. Joseph's reaction of bowing down before Jacob (v. 12) reciprocates Jacob's joy. Someone prostrating himself on the ground is certainly eyecatching. Yet, a strong negative emotion surfaces in verse 17, when Joseph discovered the crossing of Jacob's hands which would lead to 'getting it wrong.' According to ancient Near Eastern customary law, the oldest should be blessed with the right hand rather than the youngest, as Jacob intends doing. In this verse, Joseph 'was displeased' for this change

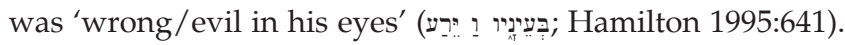
The poetic section, verses 15-16, once again (as in v. 3 and v. 4) thankfully acknowledges God's beneficial protection and abundant blessing throughout Jacob and his forebears' lives. It is clear that the narrative is filled with emotion, so much so that Von Rad (1972:416) calls it a 'dramatic scene'. The atmosphere is appropriate for the blessing ritual to be efficiently administered.

It is important that the representative of the special agent (god or ancestor), in this case Jacob, should be properly ordained, initiated or legitimised in order to act as mediator during the ritual. In special patient rituals, lay persons are allowed to conduct rituals (e.g. sacrifices) without jeopardising their validity, but an imposter in a special agent ritual nullifies its efficacy. Jacob passes the test:

The one who actually blesses is, of course, God himself ... On the other hand the human agent of blessing also plays a decisive role. He realizes that he is empowered by $\mathrm{God}^{20}$ to bestow or refuse divine blessing. (Von Rad 1972:415, [author's own emphasis])

How did Jacob become 'enabled' to acquire this? Apart from being one of the three founding fathers of Israel, his enablement came through his relationship with God. In both the additions to the 'original' narrative of Genesis 48 verses 3-6 and verse 7, and verses 15-16 - this is aptly stated. God appeared (נִראה) to Jacob at Luz (Bethel) and confirmed their intimate relationship through his continual blessing of abundant offspring, the promise of land, status and renown. Verses 15-16 ${ }^{21}$ reiterates this intimate bond between Jacob and God through its contents as well as through its form. It is presented in elevated poetry, a characteristic feature often used in the Hebrew Bible to represent communication between God and humans (e.g. Psalms; see Burden 1986:39). Verses 15-16 also reminds us of the well-known prayer of

20. Mitchell (1987:33) substantiates this: In the patriarchal promises, blessing consists of God's bestowal of descendants, fame, dominion over others, land, and God's presence and protection. In addition, God's blessing also consists of the conferral of the status of mediator of blessing upon the patriarchs.'

21.Some commentators (e.g. Hamilton 1995:633) follow the LXX or Septuagint (2nd century BCE Greek translation of the Old Testament) to change MT (Massoretic text) at the beginning of verse 15 from, 'Then he blessed Joseph ...' to 'Then he blessed them ...', as it makes more sense of what follows. However, MT can remain blessed them ...', as it makes more sense of what follows. However, MT can remain
as it is, because Joseph as their father is their representative, they are 'included' in him; he is the active senior character compared to their childlike passivity. 
Aaron, with its threefold invocation of God (Nm 6:24-26) to offer his constant and life-giving protection. The God of Jacob's forefathers, his (god-king) 'shepherd' and his guardian angel is called upon. ${ }^{22}$ The 'enabling' blessing of Jacob will likewise enable and empower Ephraim and Manasseh $^{23}$ as true carriers of Israelite culture. Through their names, the names or selves of the forebears will live. .4 Jacob's wise comment in verse 19, after refusing Joseph's correction,

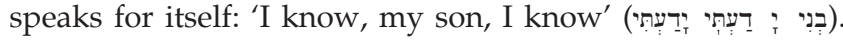
Only an enabled representative of God can utter these words with the confidence with which it is done. Skinner (1930:505) even goes as far as describing Jacob's 'knowing' as a 'supernatural impulse'. Jacob is indeed fully entitled to conduct the blessing ritual.

The blessing ritual itself consists of both words and bodily gestures that go hand-in-glove to emphasise that a deliberate action is done and, in the case of a special agent ritual, that it cannot be revoked or repeated - when it is done it is done! Nearly everything that Jacob says, markedly so the 'citations' from the past (vv. 3-6 and v. 7, and vv. 15-16) form part of the blessing. On the keyword of blessing, Mitchell (1987:84) has the following to say: 'The Piel of brk in 48:9, 15, 20 means "to pronounce a testament blessing formula."' What we have in these verses is first a request to bless (v. 9), then a prayer for blessing (v. 15) and, finally, we have the blessing proper as it becomes a fait accompli (v. 20). The names (selves) of the beneficiaries, Ephraim and Manasseh, now not only become the carriers of the ancestral names, but also the vehicle for the blessing of future Israelite generations. Following John Langshaw Austen, Mitchell (1987:8) emphasises the fact that language is not simply representational but creational, by referring to oral blessings as having both illocutionary force (it does something) and perlocutionary force (it produces effects on its recipients). This confirms McCauley and Lawson's (2002) view that rituals are indeed actions done to someone or something either through words and/or bodily actions. The perlocutionary effect of the blessing ritual is confirmed satisfactorily by the reaction of the indirect recipient, Joseph. On his sons' reaction the text is silent. Joseph prostrates himself on the ground after the poignant embracing and emotional words of his aged father in verses 8-12. The accompanying bodily gesture of the blessing of the laying on of hands has, in the past, interestingly been described as a kind of magical transfer of power or energy flowing through the arm into the recipient (Mitchell 1987:22, referring to Hempel). Mitchell (1987:84) is adamant that the laying on of hands is no more magic than a handshake today (see also Wright 1992:48). Yet, whilst this bodily gesture might not be magic, it is not meaningless (on a pre-reflexive level), as it once again confirms the action feature of rituals and that something indeed happens when doing them. If, for instance, the offered hand is rejected,

22. Hamilton (1995:637) captures the thrust of the Hebrew text aptly: "When describing his fathers' behaviour before God, Jacob uses a verb form that conveys completed action (hithallekû), which is what one expects. But when Jacob describes God's behavior toward Jacob, he uses participles, which express continuous action either in present time or in past time, which are here an equivalent to a relative cause. God has shepherded ( $r^{-\top} \mathrm{e} h$ ) him, and delivered (gó'él) him.'

23. Here, 'blessing' should not be confused with the repeated blessing at the end of a church service, or the Aaronite one of old. The blessing of Ephraim and Manasseh should rather be understood as an initiation or even ordination.

24.This expression provides a telling example of the replication function of rituals, as it maintains social stability and replicates that society (Crossley 2004:32-38). then the ritual of bonding (acknowledging shared humanity and perhaps even the same values) is nullified. The laying on of hands during the blessing seems to have a focusing or demonstrating function, identifying the recipients (Wright 1992:48). The privileged status afforded to the right hand in ancient times is not the result of some mysterious quality that it might possess, even though this impression is conveyed and believed. Most probably, it can be derived from the fact that most humans are right-handed and use their right hands more often. On this 'normal' experience are stacked all sorts of meanings, even so-called supernatural ones, to explain this 'natural' tendency. It then becomes a stereotyped, social custom that is always expected to be done thus. ${ }^{25}$

When Jacob changes the ancient social custom of switching (טכi: 'pi. eigentlich verflechten' [Westermann 1982:212]) his hands to afford the younger Ephraim the more privileged position and consequential benefits, instead of the firstborn Manasseh, Joseph intuitively senses it is wrong (vv. 17-18). He might be a 'traditionalist' (Hamilton 1995:636) but ritually speaking he has an intuitive competence to know that it is being conducted incorrectly. He 'knows' that in the case of a special agent ritual, such as the one conducted here, it cannot be withdrawn, 'a deathbed blessing is irrevocable' (Speiser 1972:358). The buck stops with the gods (McCauley \& Lawson 2002:20), for once they have acted through their representative it is over and done with! One finds exactly the same startling reaction with Jacob's father Isaac, when he realised that he blessed the younger Jacob instead of the older Esau: 'Isaac trembled violently ...' (Gn 27:33). And even though Esau earnestly requested him to put things right, Isaac remains powerless to undo what God had accomplished through the ritual.

The text is silent on the reaction of the patients or recipients Ephraim and Manasseh, but, as has been pointed out, the indirect recipient, Joseph, reacts appropriately. Perhaps it is a case of the older person grasping better than the children the ramifications of what is actually happening, just as during a baptism. Mitchell $(1987: 84,85)$ argues convincingly that the sons will be the carriers of the patriarchal promises, in spite of them being half Egyptian. In and through them, the blessing of the acquiring of Canaan (and Samaria specifically) will be realised, along with a multitude of offspring, dominion, status and renown, and so forth. The myth or story ${ }^{26}$ of the Promised Land, with all its life-giving potentialities, is reconfirmed and secured through the blessing ritual; the 'cosmos' is ordered (Gruenwald 2003:75). The participants' subjective experience of this dream awaiting them is obviously satisfactory (see, again, the reactions of Joseph and Jacob throughout the text), as is the reconfiguration of peaceful intersubjective relations. Ephraim and Manasseh are now legitimate heirs of Canaan and their fellow tribes will accept that. This is what God has done (and it is therefore not questionable) through his mediator Jacob, by way of this special agent ritual.

25.In the ancient biblical word it is interesting to note how left-handedness was frowned upon. A left-handed person was regarded as 'defective', 'sly' and even magical', for example, the left-handed Ehud uses his 'abnormal' ability to kill the at Moabite king Eglon (Jdg 3:12-30). David also uses a special corps of archers, who can comfortably ('magically') use both hands to practice their skill (1 Chr 12:2)
(Viviers 2005:801).

26.See footnote 17 


\section{The persistence of ritual behaviour}

Through the above discussions, it has become clear that rituals accomplish such remarkable subjective and intersubjective changes in the state of affairs that it is unlikely that people will get rid of them, even though they do not have intrinsic propositional meaning but rather invite the allocation of meanings by their participants. ${ }^{27}$ These special kinds of acts, where cause and effect are not really transparent and the resultant positive effects come rather 'mysteriously', open new creative spaces as they structure and order our reality. They not only uphold and replicate mainstream society but, as transformational tools, are also able to create alternative realities. Because rituals 'do' such important things, they will persist. But there are further reasons why rituals are part and parcel of humanity the world over. As has become clear already, the ability to execute them is inherently part of the normal workings of the human mind and therefore Gruenwald (2002:2) is correct in saying: 'rituals are behaviourally autonomous (that is, intrinsically independent) expressions of the human mind' (see also DeMaris 2008:8-9). However, not much more is said about the workings and structuring of the human mind. Boyer (2001:229-263) is of far greater help here by pointing out three specific mental capacities onto which ritual behaviour latches, making them salient gadgets that grab the attention of human minds rather effortlessly (Boyer 2001:231). These mental systems or tools did not evolve for rituals specifically but for normal human behaviour, of which rituals, as actions of a non-intentional kind, became a by-product. Boyer (2001) speaks of the mind's sense of urgency, social relations capacity and capacity for conceptualising superhuman agency, which rituals utilise to become so psychologically persistent amongst most humans.

The innate human sense of urgency is neatly illustrated by the fact that ritual practitioners 'feel' the need to conduct some or other ritual, usually in times of crises. Even though theatre also resembles the stereotyped actions of makebelieve according to a 'script', which is typical of rituals, a theatrical performance lacks the urgency that characterises ritual, of which the consequences are real (Boyer 2001:235). Interesting evolutionary scenarios are sketched by scholars for this intuitive sense of urgency, such as early humans' fear of pathogens (in dead carcasses, excrement, etc.) and also an extended, developed fear of unseen danger. Whatever the origins of this sense of urgency, or more concretely described as the contagion system (Boyer 2001:240), ${ }^{28}$ it exists and explains humans' often obsessive behaviour to draw boundaries, thus making places 'safe', as well as a host of purification actions. Boyer (2001:236-237) points out that many scholars have shown the similarities between obsessivecompulsive disorder (OCD) and rituals of purification, especially those that are marked by 'precautionary rules' (e.g. food preparation, ritual cleansing, baptism, etc.). The obsession that people feel to lock their doors and wash their

27. Boyer (2001:231) aptly refers to rituals as 'actions of great moment and less meaning'

28.The general cognitive alarm system (McCauley \& Lawson 2002:78; see also footnote 13) encompasses the contagion system. hands repeatedly is rather uncontrollable and, if not done or not done correctly, emotions of fear and anxiety overwhelm them. It is not only the mental tool that is present but also the energising emotions that steer behaviour in particular directions. Neuroscience and Neuropsychology have shown that OCD can be explained by the fact that certain areas of the brain responsible for planning, and the accompanying emotions that they evoke, seem to become over-activated, for instance, the contagion system. Rituals and OCD are not the same, yet many ritual scripts activate the same contagion system and are therefore just as attention-grabbing and steadfast. This system 'tells us' that our life is, to a large extent, at stake here and therefore leaves us no choice than to conduct the required ritual to put things right.

Our social mind systems become apt vehicles for rituals to become psychologically salient and embedded. Barrett (2004:3-6, 45-60) describes three types of social mental tools that regulate our social relations and are therefore called facilitators. There is the social status monitor that helps us identify different levels of status amongst people and intuitively adjust our attitudes and behaviour to become appropriate (according to societal mores ${ }^{29}$ ) in our contact with them. Then there is the social exchange regulator that intuitively guides us on 'who owes what to whom'. Lastly, we have an intuitive morality, a 'gut feeling' of right and wrong. These same tools that regulate human inter-relations are also transferred to the counterintuitive realm and utilised in transactions with the gods or ancestors. A good example of the social status monitor in action can be found in the blessing ritual of Genesis 48, as Joseph prostrates himself before his father in deference (v. 12), but simultaneously also shows utmost respect to the God whom Jacob represents. When people's status changes, for instance through a marriage, it needs to be publicly demonstrated (Boyer 2001:247) so that they can be treated accordingly. This also brings the social exchange regulator into action, as society cannot expect from them their same contribution as before. Social relations have now been realigned, so that much of their resources available to the community before are now canalised into this new family. The social exchange regulator also manages, in general, the spontaneous reciprocal behaviour that happens during a ritual. If the gods have blessed a community with good crops, their sacrifice, in turn, will thankfully acknowledge this gift; this is how it should be, no questions asked. The lesbian commitment à la marriage of McWhorter (2004) and her partner, as noted earlier, needed the acknowledgement of their immediate, heterogeneous social group and the latter could, in turn, rely on their support. But they had to signal their group-belongingness socially and publically. Boyer (2001:245) points out how warfare and other tribal rituals contributed to coalitional behaviour in early human groups, ${ }^{30}$ where all participants signalled that

29.DeMaris (2008:30), not referring to this mental tool but to ritualised action in general to negotiate social hierarchy, has the following to say: 'Catherine Bell, more than any other ritual theorist, has explored ritual activity's part in the creation of power structures.'

30.Boyer (2001:248) points out how these solidarity-based or coalitional groups are replicated today, even in massive urban settlements: 'Sociologists now find that these networks are of the same size and involve similar emotions, regardless of the country, language, size of the institution or town, and other differences.' 
they are trustworthy. Defectors cannot be tolerated in the demanding circumstances of survival. A simple ritual such as a handshake, where the stretched out hand is rejected by the other party, signals no bond and no trusting partner. Our third social tool, our intuitive morality or 'gut feeling' of right and wrong, good and bad, helps us to identify trustworthy partners. Boyer (2001:249-250) points out that we have weak social concepts but salient social intuitions. Even though we have a ToM and can infer about another's probable desires, wishes and goals, we are not able to evaluate rationally whether another person is good or bad, at least not instantly. Our intuitive morality, however, supplies us instantly with an intuition of another's integrity. A lot of pre-reflexive computational work is indeed done by the brain, of which we are not consciously aware, to supply us with the convincing feeling that the person in question is indeed somebody that can be relied on. Rituals aptly utilise this tool: if my fellow initiates do not cheat when going through excruciating, often idiotic ordeals, then surely they signal trustworthiness and reliability.

A third reason why rituals have such an irresistible appeal to our minds, and therefore persist, has to do with agency and, especially, assumed supernatural agency. Participants in rituals experience real changes in their lives through the effects of rituals. The real worlds might not have changed but the imaginative worlds in which we all live do change. The change of subjective and intersubjective experiences of realigned social relationships, of before and after the ritual (e.g. marriage) that has just been argued, provides a telling example. Something 'magic' or mysterious on which one cannot really put a finger, has brought about these changes. As a result of our massive, rather overdeveloped capacity for seeking agents everywhere, we have no alternative but to search for them and the reasons why they probably did what they did. That is the reason why conspiracy theories abound (McCauley \& Lawson 2002) and why we even ascribe and, more than often, over-ascribe, normal natural causalities (e.g. an earthquake) to some presumed anthropomorphised agent (e.g. gods or ancestors). Our HADD and ToM work overtime to detect and provide reasons for the actions of identified agents. Barrett (2004:68-69) goes so far as to describe our HADD as 'screaming' that the gods are present during a ritual of high sensory pageantry, whereas Boyer (2001:260-261) limits the function of high emotionality to a kind of social catalyst to move people to order and reorder their social worlds. Where the effects of social change are experienced as 'magical', humans can do nothing but seek for an unseen agent who is responsible for this new state of affairs. And this empty slot that occurs because of the mysterious 'unseen' is easily and intuitively filled with counterintuitive agents. The notion of counter-intuitiveness is not something strange, alien or unfamiliar to human beings, even though such agents might not really exist. Nature abounds in things that remain mysterious and inexplicable, for instance the sudden 'disappearance' of an animal through camouflage. Our mental tools easily allow for the 'real' and the 'mysterious'. The moment the unseen gods are experienced to have acted in a special agent ritual, it becomes a salient emotional and memorable experience, it 'sticks' in the mind. Boyer (2001:261-262) puts forth a convincing argument that religious and non-religious 'world-making' are not that totally different, an argument often heard nowadays in relation to how religious and secular worldviews structurally resemble each other. Nonbelievers, who nevertheless prefer to follow the same rituals as believers, for instance in regards to marriage, will argue that they do this not because of the wishes or proscriptions of some supernatural agent but merely because their 'lineage', 'tradition', 'community' or 'society' expects this of them. In the words of Richard Dawkins (2006), it implies 'loyalty to the tribe'. These anthropomorphic abstractions, however, fulfil the same function as gods or ancestors. Our minds need agency - we cannot seem to live without it. Yet, the difference, between the religious and non-religious, in terms of rituals, is the costly effort put into adhering to them. A believer will sacrifice their life because they are so 'sure' of the supernatural world, whilst the non-believer usually has similar strong reasons not to 'know' greater reality absolutely.

Boyer (2001) has the last and conclusive word on the irresistible appeal that rituals have for the human mind, explaining their persistence even though they are strange kinds of non-intentional actions:

Human minds are so constituted, with their special inference systems for unseen danger, their weak social concepts and salient social intuitions, and their notions of counterintuitive agents, that these very special performances become quite natural. (p. 263)

\section{Conclusion}

When supernatural agents are assumed to be involved in rituals as acting agents (e.g. inaugurations), usually through their enabled representatives, the ritual needs to be executed quite 'correctly', because once the gods have acted, what is done is done. These special agent rituals, therefore, also need not be repeated. In Genesis 48, Joseph intuitively knows this as he insists that Jacob does it in the accepted way, blessing the oldest son with the right hand. However, when the supernatural agents are acted upon as patients through special patient and instrument rituals (e.g. offerings or through divination), more leniency is allowed in terms of proscriptions. What humans do to gods or ancestors is not ipso facto binding on them and therefore these transactions also need to be repeated. Although rituals are counterintuitive in terms of cause and effect, they are deeds that bring about a transformation of affairs. They change our perceptions of our world and realign social relationships to ensure social stability. Echoing Michel Foucault, McCauley and Lawson (2002) have pointed out their similarity to language. As we 'set our worlds right' through discourse, we likewise reconstitute our realities through the very effective transformative tool of ritual actions. This alone explains their saliency amongst human beings. 
Apart from the transformative power that rituals possess, they appeal to the needs of the human mind and become salient gadgets, ensuring their persistence in the process. They address, usually in an emotional and motivational way, our sense of urgency, our deeply felt need to maintain sound social relations and our intuitive ability to form notions of a counterintuitive world. For all these senses, humans have developed specific mental tools to manage our lives in a welladapted manner since the early days of our species. Someone once said that he does not believe in ghosts but he is scared of them when he walks through a graveyard and can feel his hair standing up. It takes much reflexive effort to override our overactive, pre-reflective agency detection device (HADD). Even though we might rationally be convinced of the meaninglessness of many rituals, our intuitive mental tools (still) convince us of 'mysterious agency' that brings about a new state of affairs, whether that be God, gods, ancestors, spirits, 'society' or 'tradition'. This explains the feeling that something is lacking when rituals have not been conducted correctly, or at all. As long as we have the kinds of minds that we have, rituals will come naturally and will persist (Boyer 2001:263)

\section{Acknowledgements}

This article is dedicated to Prof. Piet Venter on his retirement from the Faculty of Theology, Department Old Testament Studies, University of Pretoria. Prof. Venter has been an inspiring colleague and friend for many years. His academic commitment, honesty, integrity and keen appreciation of new and innovative readings of biblical texts will always be remembered.

\section{Competing interests}

The author declares that he has no financial or personal relationship(s) which may have inappropriately influenced him in writing this article.

\section{References}

Barrett, J.L., 2004, Cognitive science of religion series: Why would anyone believe in God?, AltaMira Press, Walnut Creek.

Boyer, P., 2001, Religion explained: The evolutionary origins of religious thought, Basic Books, New York.

Burden, J.J., 1986, 'Poëtiese tekste', in F. Deist \& W. Vorster (reds.), Die Literatuur van die Ou Testament 1: Woorde wat ver kom, pp. 37-68, Tafelberg, Kaapstad.

Crossley, N., 2004, 'Ritual, body technique, and (inter)subjectivity,' in K. Schilbrack (ed.), Thinking through rituals: Philosophical perspectives, pp. 31-51, Routledge, New York.

Dawkins, R., 2006, The God delusion, Bantam Press, London.

DeMaris, R.E., 2008, The New Testament in its ritual world, Routledge, New York.

Gottwald, N.K., 1979, The tribes of Yahweh: A sociology of the religion of liberated Israel, 1250-1050 BCE, Orbis Books, Maryknoll.

Gottwald, N.K., 1985, The Hebrew Bible: A socio-literary introduction, Fortress Press, Philadelphia.

Gruenwald, I., 2003, The reference library of Judaism: Rituals and ritual theory in ancient Israel, Brill,Leiden.

Hamilton, V.P., 1995, The new international commentary of the Old Testament: The Book of Genesis: Chapters 18-50, Eerdmans, Grand Rapids.

Humphrey, C. \& Laidlaw, J., 1994, Oxford studies in social and cultural anthropology: The archetypal actions of religious ritual: A theory of ritual illustrated by the Jain rite of worship, Clarendon Press, Oxford.
rention

Martin, L.H., 2006, 'Cognitive Science, ritual, and the Hellenistic mystery religions', Religion \& Theology 13(3/4), 383-395. http://dx.10.1163/157430106779024644

McCauley, R.N., 2004, 'Philosophical naturalism and the cognitive approach to ritual', in K. Schilbrack (ed.), Thinking through rituals: Philosophical perspectives, pp. 148-171, Routledge, New York.

McCauley, R.N. \& Lawson, E.T., 2002, Bringing ritual to mind: Psychological foundations of cultural forms, Cambridge University Press, Cambridge. http://dx.10.1017/ CBO9780511606410

McWhorter, L., 2004, 'Rites of passing: Foucault, power, and same-sex commitment', in K. Schilbrack (ed.) Thinking through rituals: Philosophical perspectives, pp. 71-96, Routledge, New York.

Mitchell, C.W., 1987, The Society of Biblical Literature dissertation series 95: The meaning of brk 'to bless' in the Old Testament, Scholars Press, Atlanta.

Modéus, M., 2005, Sacrifice and symbol: Biblical Šělāmîm in a ritual perspective Almqvist \& Wicksell International, Stockholm. (Coniectanea Biblica, Old Testament series 52.)

Skinner, J., 1930, A critical and exegetical commentary on Genesis T \& T Clark, Edinburgh. (The International Critical Commentary.)

Speiser, E.A., 1964, The Anchor Bible 1: Genesis, Doubleday, New York.

Van Selms, A., 1973, De Prediking van het Oude Testament Genesis, deel II, GF Callenbach, Nijkerk.

Viviers, H., 2005, 'The politics of bodily disability', Scriptura 90(3), 799-808.

Von Rad, G., 1972, The Old Testament Library: Genesis: A Commentary, SCM, London.

Westermann, C., 1982, Biblischer Kommentar Altes Testament Genesis: 3. Teilband Genesis 37-50, Neukirchener Verlag, Neukirchen-Vluyn.

Wright, D.P., 1992, 'Hands, laying on of,' in D.N. Freedman (ed.), The Anchor Bible dictionary, vol. 3, H-J, pp. 47-48, Doubleday, New York. 